\title{
単位円上で等間隔収束する マルチェージェントシステムの初期配置に関する解析*
}

\author{
中井 優希 †・市原 裕之†
}

\author{
Initial Configuration Analysis of Multi-Agent Systems that \\ Converge to Evenly Spacing Points on Unit Circle*
}

Yuki NAKAI ${ }^{\dagger}$ and Hiroyuki ICHIHARA ${ }^{\dagger}$

\begin{abstract}
The purpose of this paper is to clarify initial configuration conditions of multi-agent systems that converge to evenly spacing points on the unit circle embedded in the control space. The agents can converge to points on the submanifold by the gradient method to maximize the distance between the agents that are mutually connected. This paper considers the cycle graph as the communication topology and the unit circle as the submanifold on the plane. Then the paper introduces the first integral of the arguments of the agents and gives a necessary and sufficient condition that the agents converge to evenly spaced points on the unit circle with the order of the cycle graph provided that the agents converge to the unit circle by the gradient method. Finally, numerical examples confirm the final configuration of the agents that satisfy the proposed initial configuration condition.
\end{abstract}

\section{1.はじめに}

マルチエージェントシステムのフォーメーション制御 では，複数のエージェントが局所的な通信によって情報 を共有し，エージェント間で共通の目標を達成する。と くに, エージェントの状態を一致させる合意制御 [1] や 制御空間内にエージェントを指定された分布で配置させ る被覆制御 [2] はよく知られている。エージェントの初 期配置と収束した最終配置の関係からこれらのフォー メーション制御について考えると，たとえば平均合意で はエージェントの初期配置を互いに交換しても最終状態 である合意值は同じにある。また，勾配法によって重心 ボロノイ配置を達成する被覆制御においては，エージェ ントの初期配置を互いに交換すると最終状態でも配置が 交換される.

一方，文献 [3] では，エージェント同士を近づけない ことが望ましいという観点から評価関数を設定し, 制御 空間内に埋め込まれた部分多様体上の等間隔点にエー ジェントを収束させることで，部分多様体の形状に沿っ

* 原稿受付 2018 年 10 月 31 日

第 61 回自動制御連合講演会にて一部を発表 [8]

†明治大学 理工学部 Faculty of Science and Engineering,

Meiji University; 1-1-1 Higashimita, Tama, Kawasaki, Kanagawa 214-8571, JAPAN

Key Words: formation control, manifold, evenly spaced points.
たフォーメーションを形成する制御手法を提案している しかし，この部分多様体上のフォーメーション制御では， 部分多様体を単位円とした場合でも，エージェントの初 期配置に対する最終配置の議論が十分ではない。エー ジェントの初期配置を互いに交換しても軌道が円周上に 到達することは保証されるが，いくつかのエージェント が同じ点に収束することがある．初期配置と最終配置の 関係をすべて明らかにすることは現時点では困難である 一方で，円上で互いに等間隔に収束するフォーメーショ ンについて明らかにすることは実用上において重要と考 えられる. 同様に, 文献 [4]では, エージェントを同期 させるという観点から評価関数を設定し，円上の等間隔 配置に関する制御について考察を行っている.

本論文では文献 [3] に基づいて，単位円上のフォーメー ション制御において，エージェントが互いに等間隔とな る点に収束するための初期配置について明らかにする。 とくに，環状グラフの通信構造に限定し 2 次元空間に 埋め込まれた単位円を部分多様体と考える。まず，マル チエージェントシステムに対して各エージェントの偏角 を用いた保存量を導入する。つぎに，この保存量を用い て，エージェントが環状グラフの通信構造と同じ順序で 互いに等間隔に収束するための条件を導く。最後に数值 例を通して, 条件を満たすエージェントの初期配置と最 終配置を確認する。本論文に関連する多様体論の用語は 付録 1.にまとめる。 


\section{2. 単位円上のフォーメーション制御}

質点系で表される 2 次元空間 $\mathbb{R}^{2}$ 上の $N$ 個のエージェ ントについて考える.

$$
\dot{p}(t)=u(t)
$$

たたし， $p=\left[\begin{array}{llll}p_{1}^{\top} & p_{2}^{\top} & \cdots & p_{N}^{\top}\end{array}\right]^{\top} \in \mathbb{R}^{2 N}, \quad p_{i}=\left[\begin{array}{ll}p_{i, x} & p_{i, y}\end{array}\right]^{\top} \in$ $\mathbb{R}^{2} \backslash\{0\}$ はエージェント $i$ の位置を表す。また, $u \in \mathbb{R}^{2 N}$ は制御入力である。すべてのエージェントを $\mathbb{R}^{2}$ 空間に 埋め込まれた部分多様体 $M$ に等間隔収束させるため，つ ぎの制御則を与える。

$$
u(t)=R(p(t))-p(t)+\operatorname{grad} \phi(R(p(t)))
$$

ただし， $R(p)=\left[r\left(p_{1}\right)^{\top} r\left(p_{2}\right)^{\top} \cdots r\left(p_{N}\right)^{\top}\right]^{\top} \in M^{N}$ で あり, $r: \mathbb{R}^{2} \rightarrow M$ は制限写像であり， $M$ 上の点を動か さない。また,

$$
\phi(R(p))=\sum_{j>i}^{N} W_{i j} \ln d\left(r\left(p_{i}\right), r\left(p_{j}\right)\right)
$$

である。ただし， $\phi: M^{N} \rightarrow \mathbb{R}, d: M \times M \rightarrow \mathbb{R}$ である とくに, $d\left(r\left(p_{i}\right), r\left(p_{j}\right)\right)$ は 2 点 $r\left(p_{i}\right), r\left(p_{j}\right) \in M$ を $M$ 上 で結ぶ短い方の測地線の距離を表す。また， $W_{i j} \in\{0,1\}$ はエージェント $i$ および $j$ の間の通信を表す重みであ る.このとき, 関数 $\phi(R(p))$ はグラフ上で隣接するエー ジェント間の相対距離を評価している，対数の性質から $\phi(R(p))$ の值は相対距離が近くなるにつれ $-\infty$ へ発散す る。エージェントが等間隔収束するためにはエージェン 卜同士の相対距離が近くなる状況を避ける必要がある。 そのため, $\phi(R(p))$ を評価関数として最大化する制御入 力 (2) 式を与えることで，エージェントの等間隔収束を 期待する。

制御則 (2) 式における勾配 $\operatorname{grad} \phi \in T_{R(p)} M^{N}$ は $\phi(R(p))$ の最急上昇方向を与えている。ゆえに，(1) 式および $(2)$ 式から成る閉ループ系において $p(t)$ は時刻の経過とと もに $\phi(R(p))$ を最大化することが期待できる。ただし， $\operatorname{grad} \phi(R(p))$ のエージェント $i$ に関するベクトルは

$$
\sum_{j=1}^{N} \frac{W_{i j}}{d\left(r\left(p_{i}(t), r\left(p_{j}(t)\right)\right)\right.} V_{i j}
$$

となる。ここで, $V_{i j} \in T_{r\left(p_{i}\right)} M$ は $r\left(p_{i}\right)$ から $r\left(p_{j}\right)$ への 単位速度べクトルであり, $T_{r\left(p_{i}\right)} M$ は $M$ 上の点 $r\left(p_{i}\right)$ に おける $M$ の接線である。このとき，時刻の経過にした がい $p(t)$ は $M^{N}$ 上に到達することが期待できる.

【補題 1】([3]) システム $(1)$ 式に対して $\phi(R(p(t)))$ を最大化するように $u(t)$ を与えるとき, $p(t) \in M^{N}$ が成 立する。

補題 1 は, 制御則 $(2)$ 式の制限写像 $r$ やエージェント間 の通信構造にかかわらず成立する。また， $p(t) \in M^{N}$ の とき $R(p(t))=p(t)$ が成立することに注意する。ある時 刻で $p(t) \in M^{N}$ が成立すれば，その時刻以降ですべての

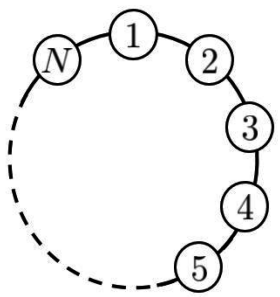

Fig. 1 Cycle graph

エージェントは $M^{N}$ 上を移動するようになる。平衡点は $M^{N}$ 上に存在するが，制御則 $(2)$ 式によって収束すると は限らない。

一方で，ある領域 $P \subset M^{N}$ に対して， $p^{*} \in P$ が $\phi\left(p^{*}\right)$ で最大值をとるとき， $p^{*}$ は漸近安定な平衡点であること が知られている $[3] . P$ は不変集合であり，平衡点に対 応した領域が存在する。つまり， $\phi\left(p^{*}\right) \geq \phi(p)$ を満たす $p \in M^{N}$ の領域である。 ある時刻で $p(t) \in P$ であれば, エージェントの軌跡は対応する平衡点へ向かうことが期 待できる. $P$ は不変集合なので, 初期状態 $p(0) \in \mathbb{R}^{2 N}$ が 属する不変集合によっても $M^{N}$ 上で収束し得る平衡点は 異なる。

以降では， $\mathbb{R}^{2}$ 空間に埋め込まれた部分多様体 $M$ とし て原点を中心とする単位円を考え，エージェントの単位 円上での等間隔点への収束を考える。このとき，単位円 上の 2 点を円周に沿って結ぶ測地線は円弧となる。 $M$ を 単位円としたときの制限写像は,

$$
r\left(p_{i}\right)=\frac{p_{i}}{\left\|p_{i}\right\|}
$$

である。ここで, $\left\|p_{i}\right\|$ は $p_{i}$ のユークリッドノルムを表 す。また，エージェント間の通信構造を Fig. 1 に示す環 状グラフとする。このとき, $W_{i j}$ は次式を満たす.

$\left\{\begin{array}{l}W_{i j}=W_{j i}=1, i \in\{1, \ldots, N\}, j=i(\bmod N)+1 \\ W_{i j}=W_{j i}=0, \text { otherwise }\end{array}\right.$

このとき，つぎの補題が成立する。

【補題 2】システム (1) 式に打けるエージェント間の 通信構造を (5) 式とする. 制限写像を (4) 式とする制御則 (2) 式を用いてすべてのエージェントが単位円上で収束 すると仮定する。このとき，通信構造上で隣り合うエー ジェント間の円弧上の長さはすべて等しくなる。すなわ ち, $i=1, \ldots, N-1$ に対して,

$d\left(r\left(p_{i}(\infty)\right), r\left(p_{i+1}(\infty)\right)\right)=d\left(r\left(p_{N}(\infty)\right), r\left(p_{1}(\infty)\right)\right)$ が成立する。

（証明）付録 2.を参照せよ。

補題 2 は, 通信構造上で隣り合うエージェントの最終 配置は単位円上で円弧に沿って等間隔をとることを述べ ている，ただし，円周上の定まった点で平衡状態をとる わけではない，等間隔となる最終配置の点は初期配置 
に依存する。また， $\phi(R(p))$ を最大化することで到達し 得るすべての平衡点は漸近安定である。逆に，不安定な 平衡点は通信構造上で隣り合うエージェント間の円弧の 長さが 0 となる配置と考えることができる，このとき， $\phi(R(p))=-\infty$ になる.

単位円上で $N$ 個のエージェントが互いに等間隔点へ 収束するとき， $\phi(R(p(\infty)))=N \log (2 \pi / N)$ となる。同 様に，偶数個のエージェントが互いに $\pi / 2$ 離れた点へ重 なりを許して収束するとき, $\phi(R(p(\infty)))=N \log (\pi / 2)$ となる。

\section{3. 初期配置条件の解析}

システム $(1)$ 式に対して制御則 $(2)$ 式は評価関数 $\phi(R(p))$ を最大化するように作用し, 補題 1 によって エージェントの単位円上に到達することが保証される。 また, $\phi(R(p))$ の最大化はグラフ構造で隣接するエー ジェント間の相対距離を引き離す方向で働くため, 補題 2 によってエージェントが単位円上の等間隔点に収束す ることが期待できることを述べた。しかしながら，これ はすべてのエージェントが単位円上で互いに等間隔な点 に収束することを意味しない。すなわち，エージェント 数と初期配置によっては，いくつかのエージェントが単 位円上の同じ点に収束し，そのような複数の点が等間隔 になることがある。つまり，そのような複数の平衡状態 が存在する.

この問題に対して，本論文では Fig. 1 に示した通信 構造の順にエージェントが単位円上で互いに等間隔収束 するための初期配置条件について考える。また以降で は，このような順序で互いに等間隔収束する場合のみ 「フォーメーションを形成する」とよぶことにする。つま り，単位円上でエージェントが時計回り順あるいは反時 計回り順に互いに等間隔収束することがフォーメーショ ンを形成することである。

そこで，エージェント $i$ の位置を

$$
p_{i}(t)=L_{i}(t)\left[\cos \alpha_{i}(t) \sin \alpha_{i}(t)\right]^{\top}
$$

と表す。ただし， $L_{i}$ は $p_{i}$ の動径， $\alpha_{i} \in[0,2 \pi)$ は $p_{i}$ の偏 角である。また，通信構造上で隣接するエージェント $i$ および $j$ に対して，エージェント $i$ から見たエージェン ト $j$ の偏角の反時計回りの差を

$$
\alpha_{i j}(t):= \begin{cases}\alpha_{j}(t)-\alpha_{i}(t), & \alpha_{j}(t)>\alpha_{i}(t) \\ 2 \pi-\left(\alpha_{i}(t)-\alpha_{j}(t)\right), & \alpha_{j}(t)<\alpha_{i}(t)\end{cases}
$$

と定義する。ここで，システム $(1)$ 式は $\phi(R(p))$ を最大 化するように制御則 $(2)$ 式によって運用されているので, すべてのエージェントが単位円上に収束する限り $\alpha_{i}$ と $\alpha_{j}$ の大小関係が逆転することはない. なぜならば， $\alpha_{i}$ と $\alpha_{j}$ が近づくと $\phi(R(p))$ が $-\infty$ へ向かうためである。つ まり，すべての時刻 $t>0$ において $\alpha_{i}(t) \neq \alpha_{j}(t)$ であり， $\alpha_{i j}(t)>0$ となる.ささらに，つぎのスカラ量を定義する.

$$
\nu(t):=\sum_{i=1}^{N-1} W_{i i+1} \alpha_{i i+1}(t)+W_{N 1} \alpha_{N 1}(t)
$$

$\nu(t)$ はグラフ上で隣接するエージェント間の偏角差の総 和を表す.とくに，Fig. 1 に示した通信構造の場合，

$$
\nu(t)=\alpha_{12}(t)+\alpha_{23}(t)+\cdots+\alpha_{N-1 N}(t)+\alpha_{N 1}(t)
$$

となる。 (8) 式で表される $\nu(t)$ に関して，つぎの補題が 成立する。

【補題 3】エージェント間の通信構造を環状グラフと するシステム (1) 式に対して, 制限写像を (4) 式とする 制御則 $(2)$ 式を用いるとき， $\nu(t)$ は保存量である.

（証明）付録 3.を参照せよ。

補題 3 は, 初期配置に依存せずに $\nu(t)$ が時刻 $t$ と関係 なく一定值をとることを述べている.

さらに，(8) 式で表される保存量 $\nu(t)$ に関して，つぎ の補題が成立する.

【補題 4】 $N$ 個のエージェントが反時計回り順およ び時計回り順で初期配置されるとき, 補題 $\mathbf{3}$ で述べた保 存量 $\nu(t)$ はつぎの值をとる.

$$
\nu(t)= \begin{cases}2 \pi, & \text { counter-clockwise } \\ 2(N-1) \pi, & \text { clockwise }\end{cases}
$$

（証明）付録 5.を参照せよ。

補題 4 は, 動径にかかわらずエージェントの偏角の順 序がFig. 1 に示した通信構造と同じ順序であれば，その 並びの向きによって保存量が一意に定まることを述べて いる.

補題 $2 \sim 4$ を用いると，エージェントの初期配置に関 してつぎの定理が成立する。

【定理 1】 システム (1) 式におけるエージェント間の 通信構造を (5) 式とする。制限写像を (4) 式とする制御則 (2) 式を用いてすべてのエージェントが単位円上で収束す ると仮定する。このとき， $\mathbb{R}^{2} \backslash\{0\}$ 上に初期配置された $N$ 個のエージェントが単位円上に反時計回り順でフォー メーションを形成するための必要十分条件は $\nu(0)=2 \pi$ である。同様に, 時計回り順でフォーメーションを形成 するための必要十分条件は $\nu(0)=2(N-1) \pi$ である。

（証明）付録 5.を参照せよ。

定理 1 はエージェントが単位円上でフォーメーション を形成するための初期配置条件を与えている。初期配置 条件は保存量によって特徴付けられ, エージェントが並 ぶ向きによって保存量の值は異なる。保存量がこれらの 值となるようにエージェントを配置するか通信構造を組 み替えることで，単位円上でエージェントが互いに等間 隔な点に収束することが保証される。

定理 1 では初期配置のみに着目しているが, すべての 時刻において $\nu(t)$ が一定であることを考慮すれば，エー ジェントの $\mathbb{R}^{2}$ 上での位置を (4) 式で単位円上に写像した 
Table 1 Initial configuration 1

\begin{tabular}{c|c}
$i$ & $\left(p_{i, x}(0), p_{i, y}(0)\right)$ \\
\hline 1 & $(1.4,0.5)$ \\
2 & $(0.6,2.0)$ \\
3 & $(-1.1,1.1)$ \\
4 & $(-1.4,1.2)$ \\
5 & $(-1.0,-0.6)$ \\
6 & $(-0.9,-1.8)$ \\
7 & $(-0.2,-1.5)$ \\
8 & $(1.6,-0.1)$
\end{tabular}

Table 2 Initial configuration 2

\begin{tabular}{c|c}
$i$ & $\left(p_{i, x}(0), p_{i, y}(0)\right)$ \\
\hline 1 & $(1.2,-0.2)$ \\
2 & $(0.9,-1.4)$ \\
3 & $(0.1,-1.6)$ \\
4 & $(-1.7,-1.5)$ \\
5 & $(-0.3,1.3)$ \\
6 & $(1.3,1.3)$ \\
7 & $(1.9,0.6)$ \\
8 & $(0.6,0.1)$
\end{tabular}

点において互いを引き離すような振舞いを常にしている ことになる。これは $\mathbb{R}^{2}$ 上のエージェントにおいても同 様であり，エージェントが単位円上に到達する時刻によ らず，互いの軌道が交わらないような振舞いをする。こ の事実は，グランドビークルのフォーメーション制御に 応用する際には衝突回避に応用できる。

\section{4. 数值例}

エージェント間の通信構造を環状グラフとするシステ ム (1) 式に対して, 制限写像を (4) 式とする制御則 (2) 式 を適用する。ただ， $N=8$, エージェントの初期配置 1 および 2 をそれぞれ Tables 1,2 とする.

初期配置 1 および 2 から始まるエージェントの軌道を Figs. 2, 3にそれぞれ示す。'メ'は初期状態，‘・'は最終状 態を表す，最終状態ですべてのエージェントが単位円上 の等間隔配置に収束している。すべての時刻における保 存量は, 初期配置 1 では約 $6.28 \approx 2 \pi$, 初期配置 2 では約 $43.98 \approx 2(N-1) \pi$ であった. したがって，どちらの初期 配置も定理 1 の条件を満たしている。このとき, 初期配 置における評価関数の值はそれぞれ約 $-4.42,-4.02$ で あり，時刻の経過とともに単調に増加し，最終配置では どちらも約 $-1.93 \approx 8 \log (2 \pi / 8)$ であった。 ゆえに, 平衡 点に収束している。

試みに初期配置 1 のエージェント 1 と 2 の配置を交換 した初期配置に対する軌道を Fig. 4 に示す。この場合, 初期配置は定理 1 の条件を満たしていない.すずての時 刻において保存量は約 12.57 となり一定であったが，最 終状態でエージェントが互いに等間隔収束していない，2

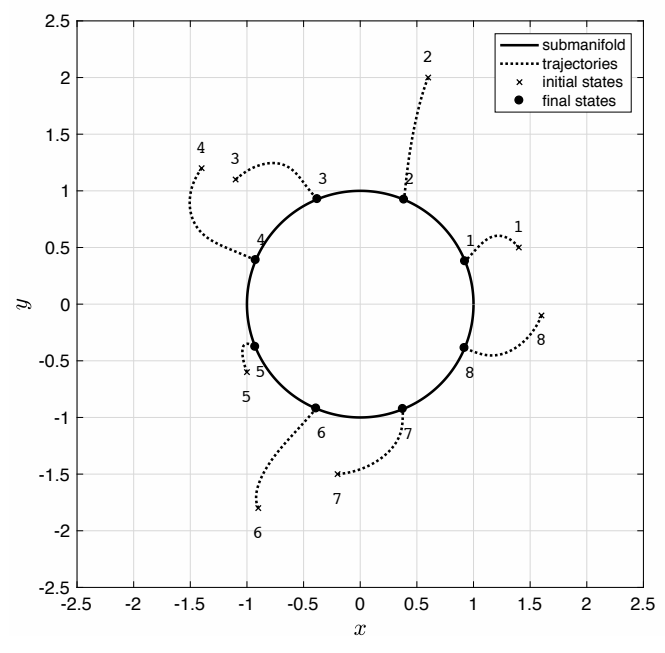

Fig. 2 Trajectory with initial configuration 1

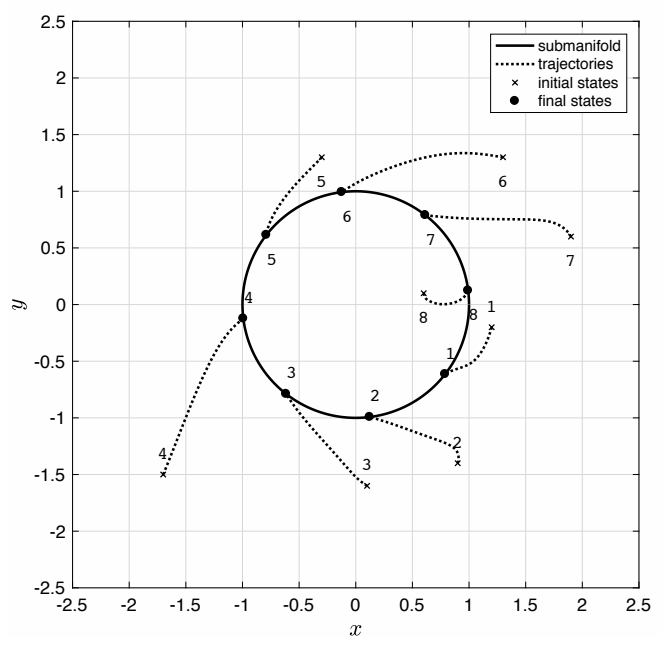

Fig. 3 Trajectory with initial configuration 2

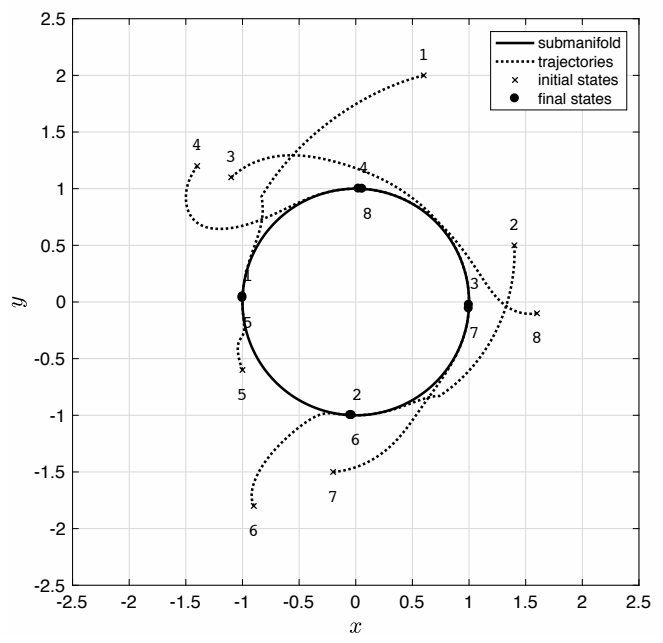

Fig. 4 Trajectory with a modified initial configuration 1

個のエージェントが同じ点に収束し，そのような 4 点が 等間隔収束している。これは本研究で目指すフォーメー ションではない。このとき, 初期配置における評価関数 の值は約 -2.59 であり, 時刻の経過とともに単調に増加 し, 最終配置では約 $3.61 \approx 8 \log (\pi / 2)$ であった。この場 
合も平衡点に収束している。

\section{5. おわりに}

本論文では，環状グラフの通信構造を有する複数の エージェントに対して，2 次元空間に初期配置し単位円 上で互いに等間隔な点に収束するための初期配置条件に ついて考えた。そのために，各エージェントの偏角から 得られる保存量を定義し, 初期状態において保存量が特 定の条件を満たす場合にエージェントが単位円上の互い に等間隔な点に収束することを明らかにした。また，数 值例で条件を満たす場合の初期配置と最終配置を確認 した。

今後は，単位円以外の部分多様体に対しても互いに等 間隔な点に収束するための初期配置条件について考える.

\section{謝辞}

本研究の一部はJSPS 科研費 JP19K0444, JP19H02158 の助成を受けたものです.

\section{参 考文 献}

[1] R. Olfati-saber, J. A. Fax and R. M. Murray: Consensus and cooperation in networked multi-agent systems; Proc. IEEE, Vol. 95, No. 1, pp. 215-233 (2007)

[2] J. Cortés, S. Martínez, T. Karatas and F. Bullo: Coverage control for mobile sensing networks; IEEE Transactions on Robotics and Automation, Vol. 20, No. 2, pp. 243-255 (2004)

[3] J. M. Montenbruck, D. Zelazo and F. Allgöwer: Fekete points, formation control, and the balancing problem; IEEE Transactions on Automatic Control, Vol. 62, No. 10, pp. 5069-5081 (2017)

[4] D. A. Paley, N. E. Leonard, R. Sepulchre, D. GrÜnbaum and J. K. Parrish: Oscillator models and collective motion; IEEE Control Systems Magazine, Vol. 27, No. 4, pp. 89-105 (2007)

[5] 松本: 多様体の基礎, 東京大学出版会 (1988)

[6] G. E. Bredon: Topology and Geometry, Springer (1993)

[7] 児玉, 須田: システム制御のためのマトリクス理論, コ ロナ社 (1981)

[8] 中井, 市原: 部分多様体上で等間隔収束するマルチエー ジェントシステムの初期配置に関する解析; 第 61 回自動 制御連合講演会予稿集 (2018)

\section{付 録}

付録 1. 多様体に関する用語

【定義 1】（[5], pp. 38-39）位相空間 $M$ が次の 2 条 件を満たすとき， $M$ を $m$ 次元多様体という.

1. $M$ はハウスドルフ空間である.

2. $M$ の任意の点 $p$ について, $p$ を含む $m$ 次元座標近 傍が存在する。

【定義 2】 ([5], p. 155) 写像 $f: M \rightarrow N$ を $C^{r}$ 級

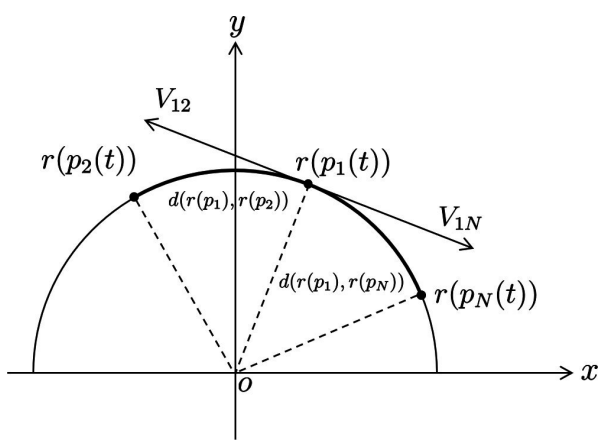

Fig. A1 Unit velocity vector on geodesics

$(r=1,2, \ldots)$ とする. $f$ が埋め込みであるとは, 以下の 2 条件が成り立つことである。

1. すべての点 $p \in M$ について, $f$ の微分

$(d f)_{p}: T_{p} M \rightarrow T_{f(p)} N$ が単射である.

2. $f$ が $M$ から像 $f(M)$ への同相写像である.

ただし， $T_{p} M$ は点 $p$ における $M$ の接空間を表す.

【定義 3】 ([6], p. 42) $X$ を位相空間, $A$ を $X$ の部 分空間とする。このとき, 連続写像 $f: X \rightarrow A$ が引き 込み (retraction) であるとは，すべての $a \in A$ に対して $f(a)=a$ が成り立つことをいう.

定義 3 において, $f$ の $A$ への制限, つまり $f$ の定義域 を $A$ に制限した写像 $\left.f\right|_{A}$ ，は制限写像とよばれる。いま の場合, $\left.f\right|_{A}: A \rightarrow A$ は同相写像になり, 定義 2 の条件 2 を満たす． $f(a)=a$ であることから, 引き込み $f$ は制限 写像 $\left.f\right|_{A}$ が恒等写像になる写像ということもできる. 以 上のように，引き込みは制限写像の一種ではあるが，本 文中では引き込みを単に制限写像と表記している.

\section{付録 2. 補題 2 の証明}

すべてのエージェントが単位円上で収束するとき，制 御入力 $(2)$ 式を 0 にする勾配 $\operatorname{grad} \phi(r(p))$ のエージェン 卜 $i$ に関する成分は $(3)$ 式である。通信構造 $(5)$ 式を考慮 して $, i=1, \ldots, N$ に関して $(3)$ 式を展開すると，つぎの ようになる。

$$
\left\{\begin{array}{l}
\frac{1}{d_{12}} V_{12}+\frac{1}{d_{1 N}} V_{1 N}=0 \\
\frac{1}{d_{21}} V_{21}+\frac{1}{d_{23}} V_{23}=0 \\
\frac{1}{d_{32}} V_{32}+\frac{1}{d_{34}} V_{34}=0 \\
\vdots \\
\frac{1}{d_{N-1 N-2}} V_{N-1 N-2}+\frac{1}{d_{N-1 N}} V_{N-1 N}=0 \\
\frac{1}{d_{N N-1}} V_{N N-1}+\frac{1}{d_{N 1}} V_{N 1}=0
\end{array}\right.
$$

ただし， $d_{i j}=d\left(r\left(p_{i}(\infty)\right), r\left(p_{j}(\infty)\right)\right) \in[0, \pi]$ とする，た とえば，エージェント 1 に関する単位速度べクトルと 円弧を Fig. A1 に示す。平衡状態では図のように 2 本 のベクトル $V_{12}$ と $V_{1 N}$ は互いに真逆の方向を向くので, 
$V_{1 N}=-V_{12}$ である. 同様に考えると， $V_{21}=-V_{23}, V_{32}=$ $-V_{34}, \ldots, V_{N-1 N-2}=-V_{N-1 N}, V_{N N-1}=-V_{N 1}$ である. $d_{i j}=d_{j i}$ を考慮すると， (3) 式は $E \alpha=0$ とまとめること ができる。ただし，

$$
E=\left[\begin{array}{cccccc}
1 & 0 & 0 & \cdots & \cdots & -1 \\
-1 & 1 & 0 & \cdots & \cdots & 0 \\
0 & -1 & 1 & \cdots & \cdots & 0 \\
\vdots & & \ddots & \ddots & & \vdots \\
0 & \cdots & \cdots & -1 & 1 & 0 \\
0 & \cdots & \cdots & 0 & -1 & 1
\end{array}\right], \alpha=\left[\begin{array}{c}
1 / d_{12} \\
1 / d_{23} \\
1 / d_{34} \\
\vdots \\
1 / d_{N-1 N} \\
1 / d_{N 1}
\end{array}\right]
$$

とする. 行列 $E \in \mathbb{R}^{N \times N}$ は, 周期 $N$ の既約な確率行列 $P \in \mathbb{R}_{+}^{N \times N}$ と $N$ 次単位行列 $I_{N}$ を用いて, $E=I_{N}-P$ と 表すことができる。一般に，既約な確率行列は実固有值 1 を有する $[7$, p. 307]. また， $P$ は非負な既約行列であ るため, ペロン・フロベニウス定理 $[7$, p. 304] から，ス ペクトル半径に等しい代数的重複度 1 の実固有值を有し 対応する固有べクトルは正ベクトルである。いま，Pの スペクトル半径に等しい固有值は 1 であり，対応する固 有べクトルは $\mathbf{1}_{N} s(s \neq 0)$ と表すことができる。ゆえに， $P \mathbf{1}_{N} s=\mathbf{1}_{N} s$ が成立する。ただし， $\mathbf{1}_{N}$ はすべての要素 が1の $N$ 次べクトルである。 このとき， $\left(I_{N}-P\right) 1 s=0$ であることから， $E$ は代数的重複度 1 の零固有值を有し 対応する固有べクトルは $\alpha=1 s$ であると解釈できる。し たがって，(6) 式が成立する。

\section{付録 3. 補題 3 の証明}

偏角差 $\alpha_{i j}$ の時間微分は, (7) 式より

$$
\dot{\alpha}_{i j}=\dot{\alpha}_{j}-\dot{\alpha}_{i}
$$

となる.ここで, $(7)$ 式で定義される $\alpha_{i j}(t)$ は時刻 $t$ に関 して連続である一方, 偏角 $\alpha_{i}(t) \in[0,2 \pi)$ は偏角 0 を横 切る時刻において連続ではない. しかしながら，そのよ うな時刻の直前と直後で偏角の時間微分は一致する。ま た，(8) 式の時間微分は,

$$
\dot{\nu}=\dot{\alpha}_{12}+\dot{\alpha}_{23}+\cdots+\dot{\alpha}_{N-1 N}+\dot{\alpha}_{N 1}
$$

である。(A2) 式を (A1) 式に代入すれば

$$
\begin{aligned}
\dot{\nu}= & \left(\dot{\alpha}_{2}-\dot{\alpha}_{1}\right)+\left(\dot{\alpha}_{3}-\dot{\alpha}_{2}\right) \\
& +\cdots+\left(\dot{\alpha}_{N}-\dot{\alpha}_{N-1}\right)+\left(\dot{\alpha}_{1}-\dot{\alpha}_{N}\right) \\
= & 0
\end{aligned}
$$

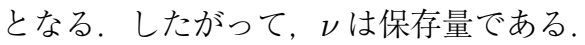

\section{付録 4. 補題 4 の証明}

必要性: (a) $N$ 個のエージェントが反時計回り順で初期 配置されると仮定する。このときの一般性を失わない初 期配置例を Fig. A2 に示す，矢印は偏角差を表す．保存量 は $(8)$ 式であるので, 図より明らかに $\nu(t)=2 \pi$ である.

(b) $N$ 個のエージェントが時計回り順で初期配置される と仮定する. 同様な初期配置例を Fig. A3に示す.ただし,

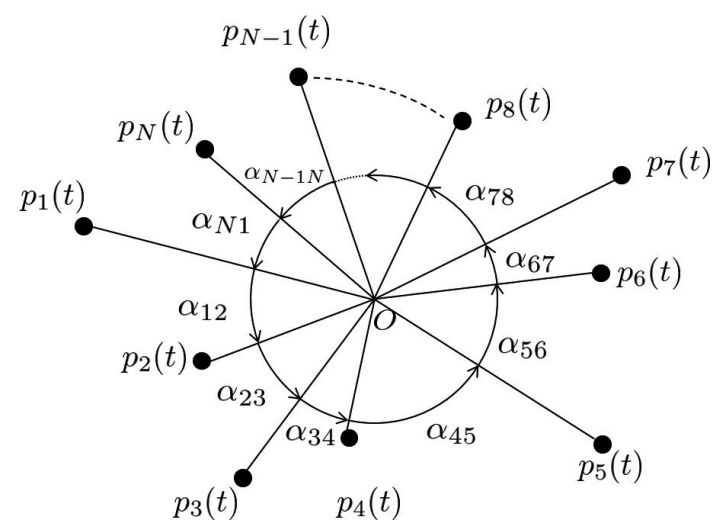

Fig. A2 Initial configuration with counter-clockwise

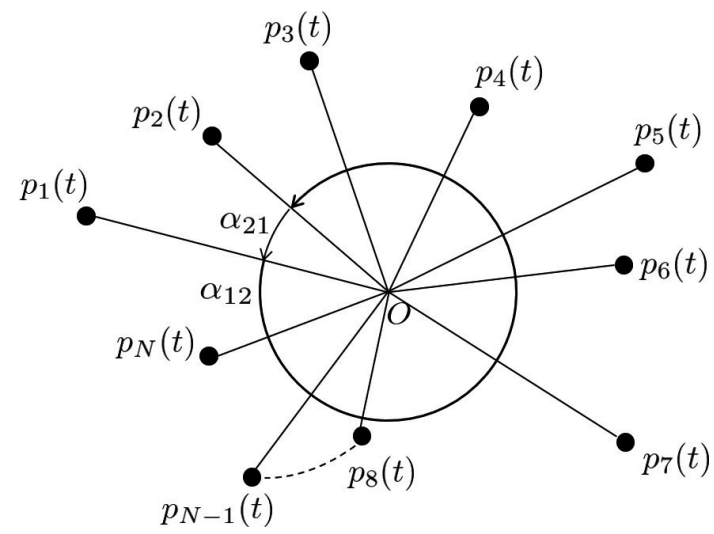

Fig. A3 Initial configuration with clockwise

議論の対象となる偏角差は一部のみ表記している。エー ジェント 1 と 2 の偏角差に着目すると， $\alpha_{12}=2 \pi-\alpha_{21}$ である. $\alpha_{23}, \alpha_{34}, \ldots, \alpha_{N 1}$ についても同様に考えると，

$$
\begin{aligned}
\alpha_{12}= & 2 \pi-\alpha_{21} \\
\alpha_{23}= & 2 \pi-\alpha_{32} \\
\vdots & \vdots \\
\alpha_{N-1 N}= & 2 \pi-\alpha_{N N-1} \\
\alpha_{N 1}= & 2 \pi-\alpha_{1 N}
\end{aligned}
$$

となる。保存量はこれらの総和であるため,

$$
\nu(t)=2 N \pi-\left(\alpha_{21}+\alpha_{32}+\cdots+\alpha_{N N-1}+\alpha_{1 N}\right)
$$

となる。ここで，(a) と同様に考えれば上式の括弧内は $2 \pi$ である。したがって， $\nu(t)=2(N-1) \pi$ を得る.

十分性: (a) $\nu(t)=2 \pi$ と仮定する. 保存量 (8) 式の偏角差 $\alpha_{i j}$ を(7) 式で展開すれば, 偏角 $\alpha_{i}(i=1, \ldots, N)$ はすべ て打ち消され $2 \pi$ が残ることになる。 このとき， $\alpha_{j}<\alpha_{i}$ となる偏角差 $\alpha_{i j}$ に関するエージェント $i$ および $j$ の組 $(i, j)$ が 1 箇所存在する。 その 1 箇所は偏角差を表す矢印 が角 0 を横切る場合に生じる。そこで，その 1 箇所とな る $(i, j)$ を任意に与え, 他の箇所ではすべて $\alpha_{j}>\alpha_{i}$ と なるようにエージェントを初期配置することを考える。 一般性を失わない初期配置例を Fig. A4 に示す. 図では, $\alpha_{j}<\alpha_{i}$ となる偏角差 $\alpha_{i j}$ に関する組 $(i, j)$ を $(N, 1)$ とし 


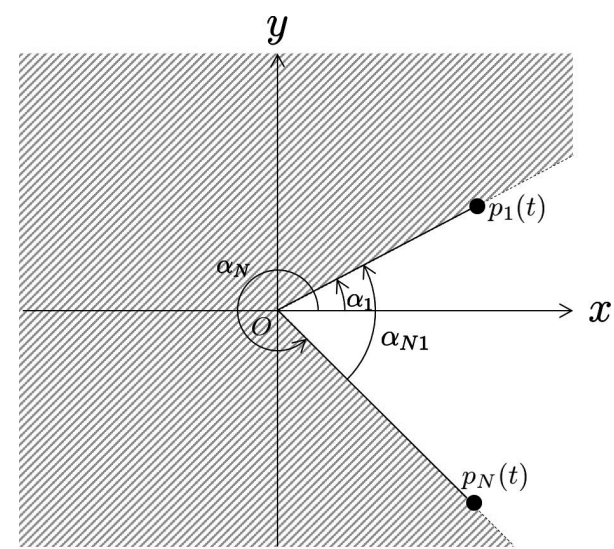

Fig. A4 Configuration of $\alpha_{1}<\alpha_{N}$

ている.このとき, $\alpha_{N 1}=2 \pi-\left(\alpha_{N}-\alpha_{1}\right)$ となることが 確認できる. $\nu(t)=2 \pi$ であるので, 環状グラフにおいて 互いに隣り合うエージェントに関しては $(i, j)=(N, 1)$ 以

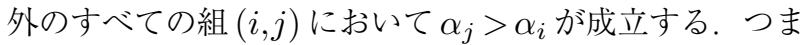
り, $(i, j)=(1,2)$ については $\alpha_{2}>\alpha_{1}, \quad(i, j)=(N-1, N)$ については $\alpha_{N}>\alpha_{N-1}$ となるように配置される.この議 論を続けると，エージェント 2 から $N-1$ までは Fig. A4 の斜線領域に反時計回り順に初期配置される.

(b) $\nu(t)=2(N-1) \pi$ と仮定する. 保存量 (8) 式の偏 角差 $\alpha_{i j}$ を $(7)$ 式で展開すれば, $\alpha_{i}(i=1, \ldots, N)$ はすべ て打ち消され $2(N-1) \pi$ が残ることになる，このとき， $\alpha_{j}<\alpha_{i}$ となる偏角差 $\alpha_{i j}$ に関するエージェント $i$ および $j$ の組 $(i, j)$ が $N-1$ 箇所存在する。これは， $\alpha_{j}>\alpha_{i}$ とな る組 $(i, j)$ が 1 箇所存在することを意味する。 その 1 箇所 は偏角差を表す矢印が角 0 を横切ることはない。 そこで, その 1 箇所となる $(i, j)$ を任意に与え，他の箇所ではすべ て $\alpha_{j}<\alpha_{i}$ となるようにエージェントを初期配置するこ とを考える。一般性を失わない初期配置例を Fig. A5に 示す．図では， $\alpha_{j}>\alpha_{i}$ となる偏角差 $\alpha_{i j}$ に関する組 $(i, j)$ を $(N, 1)$ としている。 このとき， $\alpha_{N 1}=\alpha_{1}-\alpha_{N}$ となる ことが確認できる。 $\nu(t)=2(N-1) \pi$ であるので，環状 グラフにおいて互いに隣り合うエージェントに関しては $(i, j)=(N, 1)$ 以外のすべての組 $(i, j)$ において $\alpha_{j}<\alpha_{i}$ が成立する。つまり， $(i, j)=(1,2)$ については $\alpha_{2}<\alpha_{1}$, $(i, j)=(N-1, N)$ については $\alpha_{N}<\alpha_{N-1}$ となるように 配置される。この議論を続けると，エージェント 2 から $N-1$ までは Fig. A5 の斜線領域に時計回り順に初期配 置される

\section{付録 5. 定理 1 の証明}

必要性：すべてのエージェントが通信構造と同じ順に単 位円上で反時計回り順に互いに等間隔な点へ収束すると 仮定する。 このとき，補題 4 より $\nu(\infty)=2 \pi$ である。 ま た, 補題 3 より $\nu(t)$ は保存量であるため $\nu(0)=2 \pi$ で ある。

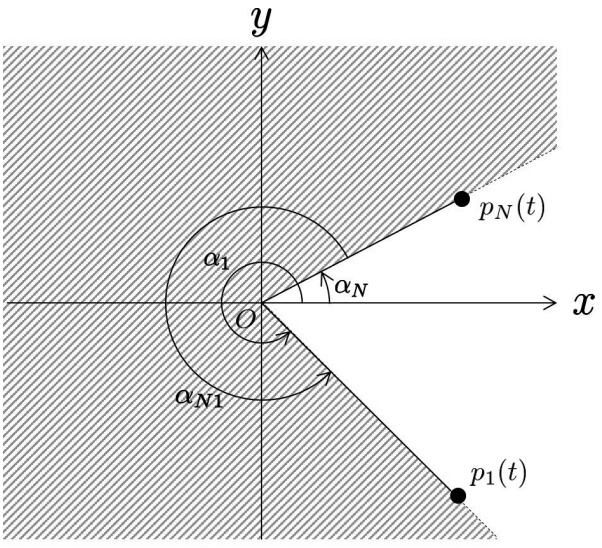

Fig. A5 Configuration of $\alpha_{1}>\alpha_{N}$

時計回り順に互いに等間隔な点へ収束すると仮定する 場合も同様に示すことができる.

十分性: $\nu(0)=2 \pi$ と仮定する。 このとき, 補題 4 よりす ベてのエージェントは反時計回り順で初期配置されてい る. 補題 3 より $\nu(t)$ は保存量であるため $\nu(\infty)=2 \pi$ であ る. よって, 最終状態においては反時計回り順で収束する. また, 補題 2 より $i=1, \ldots, N-1$ について (6) 式が成立す る.このとき, 通信構造上で隣り合うエージェント $i$ およ゙ $j$ を結ぶ円弧の長さは $\alpha_{i j}(\infty)=d\left(r\left(p_{i}(\infty)\right), r\left(p_{j}(\infty)\right)\right)$ である。したがって，すべてのエージェントは反時計回 り順で単位円上に互いに等間隔な点に収束する.

$\nu(0)=2(N-1) \pi$ と仮定する場合も同様に示すことが できる。

\section{著 者略 歴}

妿井要竞

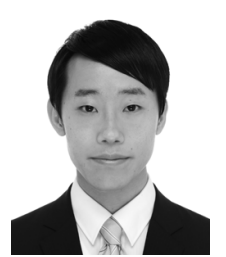

2017 年 3 月明治大学理工学部機械情報 工学科卒業, 2019 年 3 月明治大学大学院 理工学研究科機械工学専攻博士前期課程修 了. 現在，三菱電機株式会社に勤務．在学 中，マルチエージェントシステムの制御に 興味をもつ。

等原裕希 (正会員)

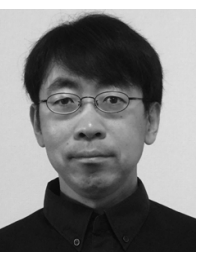

2000 年 3 月明治大学大学院理工学研究 科機械工学専攻博士後期課程修了. 同年 4 月明治大学理工学部助手, 2001 年 7 月茨 城大学大学院理工学研究科 SVBL 非常勤 研究員, 2002 年 4 月九州工業大学情報工 学部助手, 2010 年 4 月明治大学理工学部 専任講師, 2013 年 10 月同准教授, 2019 年 4 月同教授となり 現在に至る。 2016 年 4 月から 1 年間 LAAS-CNRS（フラン ス) 客員研究員. 制御工学の研究に従事. 博士 (工学). 計 測自動制御学会, IEEEの会員. 